\title{
Statyba
}

ISSN: 1392-1525 (Print) (Online) Journal homepage: https://www.tandfonline.com/loi/tcem19

\section{PROPERTY VALUATION BY MULTIPLE CRITERIA METHODS}

\author{
V. Malienė , E. K. Zavadskas , A. Kaklauskas \& S. Raslanas
}

To cite this article: V. Malienè , E. K. Zavadskas , A. Kaklauskas \& S. Raslanas (1999) PROPERTY VALUATION BY MULTIPLE CRITERIA METHODS, Statyba, 5:4, 272-284, DOI: 10.1080/13921525.1999.10531475

To link to this article: https://doi.org/10.1080/13921525.1999.10531475

曲 Published online: 26 Jul 2012.

Submit your article to this journal $\pi$

LII Article views: 317

4 Citing articles: 1 View citing articles 준 


\title{
NEKILNOJAMOJO TURTO VERTINIMAS DAUGIAKRITERINIU METODU
}

\author{
V. Maliené, E. K. Zavadskas, A. Kaklauskas, S. Raslanas
}

\section{1. [vadas}

Vokietijoje taikomi daugiakriteriniai vertinimo metodai priklauso atskirai nekilnojamojo turto vertès nustatymo metodu grupei. Nekilnojamojo turto vertinimo praktikoje šiuos metodus pradèta taikyti jau nuo $1976 \mathrm{~m}$. Dr. H. E. Auernhammeris [1] šiais metodais pirmasis bandè išspresti nekilnojamojo turto vertinimo problema, kylančią dèl rinkos duomenų trūkumo. Vèliau metodas buvo papildytas ivairių autoriu sudarytomis faktoriu sistemomis ir pritaikytas vertinant skirtingu paskirčiu, taip pat ypatingus nekilnojamojo turto objektus, kai nèra rinkos duomenu (pirkimo ir pardavimo ar nuomos kainu), ju trūksta arba negalima objektų techniškai jvertinti trimis klasikiniais nekilnojamojo turto vertinimo metodais. $\mathrm{Pa}$ vyzdžiui, K. Gablenzas [2] siūlo ši metodą taikyti žemès ūkio paskirties žemès sklypams vertinti, B. Bischofas [3] - investicijoms $\mathfrak{i}$ žemès sklypus vertinti, R. Vogelis [4] apytiksliai nustatyti žemès vertę, G. Sommeris, P. Zimmermannas [5] ir Piehleris [6] sudarè tipines faktoriu sistemas, kuriomis remiantis šiuo metodu galima apskaičiuoti lyginamojo ir vertinamojo nekilnojamojo turto objektų kiekybės, kokybès ir rinkos konjunktūrų skirtumus. T. Gerardy's ir R. Moeckelis [7] analizavo daugiakriterinès analizès metodụ privalumus ir trūkumus.

Šie metodai taikomi šių dienų Vokietijos nacionalinèje rinkoje, ypač plačiai jie buvo taikomi 1990 m., susijungus VDR ir VFR [8].

Šiame straipsnyje pateiktą autorių daugiakriterini vertinimo metoda gali taikyti ivairios nekilnojamuoju turtu suinteresuotos žmonių grupès (1 pav.). Kiekviena žmoniu grupe, pvz., vertintojas, pirkèjas, pardavèjas ar investuotojas ji gali taikyti ivairiais aspektais:

- vertintojas - nekilnojamojo turto analizei atlikti, turto rinkos vertei, naudojimo vertei ar kitoms vertèms nustatyti turtą ikeičiant, apdraudžiant, privatizuojant, dalijant ar paimant visuomenès poreikiams;
- investuotojas siekia turtą panaudoti maksimaliai efektyviai ir geriausiai;

- pirkejas yra suinteresuotas išsirinkti turtą, kuris maksimaliai patenkintu jo asmeninius poreikius;

- pardavejjas privalo nustatyti turto konkurencingas kainas rinkoje, kad preké būtų konkurencinga.

Išardytiems tikslams igyvendinti gali būti taikomas daugiakriterinis vertinimo metodas, kuris ir pateikiamas šiame straipsnyje, taip pat pateikiamas metodo taikymo pavyzdys.

\section{Sprendimų prièmimo matricos sudarymas}

Nekilnojamojo turto daugiakriterinei analizei atlikti būtina parengti sprendimų prièmimo matricą (1 lent.), kuri sudaroma keliais etapais:

- kriterijų apibūdinančių suinteresuotu žmoniu grupių tikslus, nustatymas;

- variantus apibūdinančių kriterijų matavimo vienetų reikšmių ir reikšmingumų nustatymas;

- kriteriju, ju reikšmių ir reikšmingumų grupavimas matriciniu pavidalu.

Vertinamojo ir lyginamujų objektų analizès rezultatai pateikiami sprendimu prièmimo matricos pavidalu, kur stulpeliuose pateikiami nagrinejjami n objektai, o eilutèse - kiekybinè ir koncepcinè informacija, išsamiai apibūdinanti nagrinejamus variantus. Vertinamaji ir lyginamuosius objektus aprašydami kiekybine ir koncepcine formomis, pateikiame ivairius ju aspektus (ekonominius, techninius, technologinius, infrastruktūrinius, architektūrinius, estetinius, komfortinius, teisinius, socialinius) apibūdinančią informaciją. Kiekybinè informacija apima kriteriju sistemas, matavimo vienetus, reikšmes ir pradinius reikšmingumus, minimizuojanti ar maksimizuojanti kriteriju. informaciją apie lyginamujų objektų parinkimą.

Aprašant vertinamaji ir lyginamus objektus koncepcine forma, tekstu, schemomis, grafikais, diagramomis, 


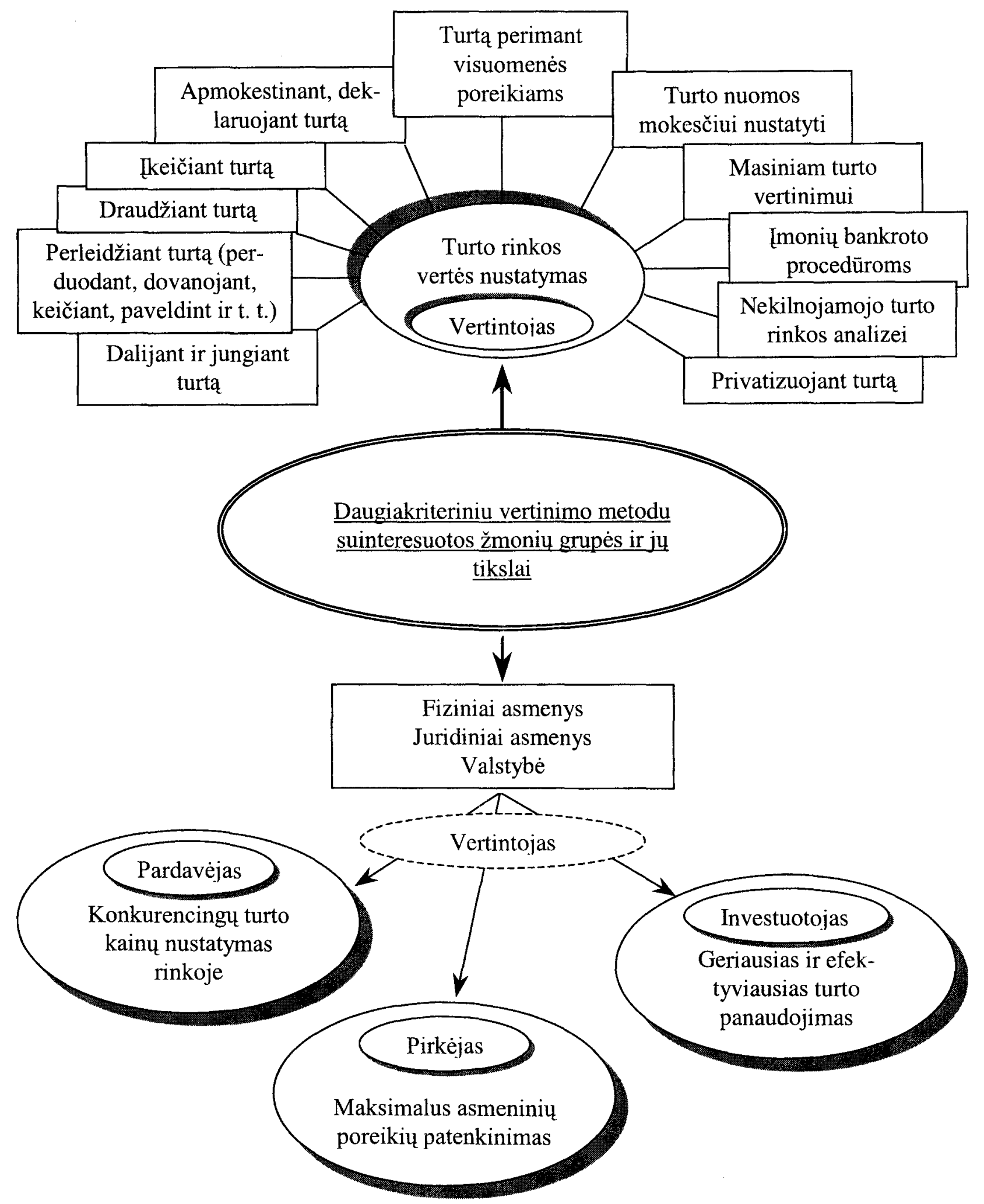

1 pav. Daugiakriteriniu vertinimo metodu suinteresuotos žmonių grupès ir jų tikslai

Fig 1. Interested parties using multiple criteria valuation methods and their particular needs 
bréžiniais ir vaizdajuostemis pateikiama koncepcinè informacija apie objektus ir juos išsamiai apibūdinančius kriterijus (jų aprašymas, priežastys ir pagrindimas, kuriais remiantis buvo nustatyta kriterijų sistema, reikšmès ir reikšmingumai). Koncepcinès informacijos reikia norint išsamiau ir tiksliau jvertinti nagrinejamus variantus, t. y. ji ne tik padeda gauti išsamesnès informacijos, bet ir tiksliau sudaryti kriteriju sistemą, nustatyti kriterijų reikšmes ir reikšmingumus.

Sprendimu prièmimo matricoje kriterijai grupuojami $\mathfrak{i}$ dvi grupes: kiekybinius ir kokybinius. Taip lengviau atlikti variantų daugiakriterinę analizę, taip pat geriau bus matoma skaiciavimų fizinè prasmè. Atliekant nekilnojamojo turto objektų daugiakriterinę analizę dažniausiai operuojama didelès apimties informacija, todèl ją racionalu apdoroti matriciniu būdu. Šiuo atveju nagrinèjami variantai, juos apibūdinanti kiekybinè ir koncepcinè informacija grupuojamos tam tikra tvarka, t. y. sudaroma vertinamojo ir lyginamuju nekilnojamojo turto objektц daugiakriterinés analizès sugrupuota sprendimų prièmimo matrica.

Norint išrinkti efektyviausią nekilnojamojo turto objektą ar nustatyti jo rinkos verte, reikia, sudarius spren- dimų prièmimo matrica, atlikti nekilnojamojo turto objektų daugiakriterinę analizę. Tai atliekama lyginant nagrinejjamı projektı kriteriju reikšmes ir reikšmingumus, analizuojant koncepcinę informaciją. Nagrinėjamus nekilnojamojo turto objektus galima apibūdinti tik remiantis daugelio skirtinga prasmę ir dimensijas turinčių kriterijų sistema.

Pagrindiniai kriterijų sistemos sudarymo principai ir pagal juos sudaryti pavyzdžiai yra pateikti [9-11]

Konkretaus kriterijaus reikšmingumo fizinè prasmẻ yra ta, kad jis parodo, kiek jis yra naudingas nekilnojamojo turto objektui ir kiek kartų naudingumas didesnis (mažesnis) už kito kriterijaus naudinguma, kompleksiškai vertinant nekilnojamojo turto objektus. Kokybinių kriterijų reikšmès ir kriteriju pradiniai reikšmingumai dažniausiai nustatomi ekspertiniu bũdu.

\section{Daugiakriterinis vertinimo metodas}

Vertinamo objekto rinkos vertè nustatoma artejimo büdu per kelis ir daugiau metodo artèjimo ciklus, kol vertinamo objekto $a_{x}$ naudingumo procento $N_{j}$ vidutinis nukrypimas $k_{x}$ atitinka salyga $\left|k_{a x}\right|<1 \%$.

1 lentelẻ. Nagrinéjamų objektų daugiakriterinès analizés sugrupuota sprendimų prièmimo matrica

Table 1. A grouped decision-making matrix of multiple criteria analysis applied to the objects considered

\begin{tabular}{|c|c|c|c|c|c|c|c|c|c|}
\hline \multicolumn{10}{|c|}{ Kiekybinè informacija, apibūdinanti objektus } \\
\hline \multirow[t]{2}{*}{ Nagrinejami kriterijai } & & \multirow{2}{*}{$\begin{array}{l}\text { Reikšmin- } \\
\text { gumas }\end{array}$} & \multirow{2}{*}{$\begin{array}{l}\text { Matavimo } \\
\text { vienetai }\end{array}$} & \multicolumn{6}{|c|}{ Nagrinejami objektai } \\
\hline & & & & 1 & 2 & $\ldots$ & $\mathrm{j}$ & $\ldots$ & $n$ \\
\hline \multirow{6}{*}{ Kiekybiniai kriterijai } & $\check{Z}_{1}$ & $q_{1}$ & $\mathrm{~m}_{1}$ & $\mathrm{x}_{11}$ & $\mathrm{x}_{12}$ & $\ldots$ & $x_{1 j}$ & $\ldots$ & $x_{\text {ln }}$ \\
\hline & $\check{z}_{2}$ & $\mathrm{q}_{2}$ & $\mathrm{~m}_{2}$ & $x_{21}$ & $x_{22}$ & $\cdots$ & $x_{2 j}$ & $\ldots$ & $x_{2 n}$ \\
\hline & $\ldots$ & $\cdots$ & $\ldots$ & $\ldots$ & $\ldots$ & $\cdots$ & $\cdots$ & $\ldots$ & $\ldots$ \\
\hline & $\breve{z}_{i}$ & $\mathrm{q}_{\mathrm{i}}$ & $\mathrm{m}_{\mathrm{i}}$ & $x_{i 1}$ & $\mathrm{x}_{\mathrm{i} 2}$ & $\cdots$ & $\mathrm{x}_{\mathrm{ij}}$ & $\ldots$ & $\mathrm{x}_{\mathrm{in}}$ \\
\hline & $\cdots$ & $\cdots$ & $\cdots$ & $\ldots$ & $\cdots$ & $\cdots$ & $\cdots$ & $\ldots$ & $\cdots$ \\
\hline & $\check{z}_{t}$ & $\mathrm{q}_{\mathrm{t}}$ & $\mathrm{m}_{\mathrm{t}}$ & $x_{t 1}$ & $x_{t 2}$ & $\ldots$ & $x_{t j}$ & $\ldots$ & $x_{\text {tn }}$ \\
\hline \multirow{6}{*}{ Kokybiniai kriterijai } & $\check{Z}_{t+1}$ & $q_{t+1}$ & $m_{t+1}$ & $x_{t+1} 1$ & $x_{t+12}$ & $\cdots$ & $x_{t+1} j$ & $\ldots$ & $x_{t+1 n}$ \\
\hline & $\check{Z}_{t+2}$ & $q_{t+2}$ & $m_{t+2}$ & $x_{t+21}$ & $x_{t+22}$ & $\ldots$ & $x_{t+2 j}$ & $\ldots$ & $x_{t+2 n}$ \\
\hline & $\ldots$ & $\cdots$ & $\ldots$ & $\ldots$ & $\cdots$ & $\cdots$ & $\ldots$ & $\ldots$ & $\ldots$ \\
\hline & $\breve{z}_{\mathrm{i}}$ & $q_{i}$ & $\mathrm{~m}_{\mathrm{i}}$ & $\mathrm{x}_{\mathrm{i} 1}$ & $x_{i_{2}}$ & $\cdots$ & $\mathrm{x}_{\mathrm{ij}}$ & $\cdots$ & $x_{\text {in }}$ \\
\hline & $\ldots$ & $\ldots$ & $\ldots$ & $\ldots$ & ... & $\ldots$ & $\ldots$ & $\ldots$ & $\ldots$ \\
\hline & $\breve{\mathrm{z}}_{\mathrm{m}}$ & $\mathrm{q}_{\mathrm{m}}$ & $\mathrm{m}_{\mathrm{m}}$ & $\mathrm{x}_{\mathrm{mi}}$ & $\mathrm{x}_{\mathrm{m} 2}$ & $\ldots$ & $\mathrm{x}_{\mathrm{mj}}$ & $\ldots$ & $\mathrm{x}_{\mathrm{mn}}$ \\
\hline \multicolumn{10}{|c|}{ Koncepciné informacija, apibūdinanti objektus (tekstas, brěžiniai, grafikai, vaizdajuostès) } \\
\hline $\mathrm{K}_{\mathrm{k}}$ & $\mathrm{K}_{\check{z}}$ & $\mathrm{~K}_{\mathrm{q}}$ & $\mathrm{K}_{\mathrm{m}}$ & $\mathbf{K}_{1}$ & $\mathrm{~K}_{2}$ & 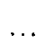 & $\mathbf{K}_{\mathrm{j}}$ & .. & $\mathrm{K}_{\mathrm{n}}$ \\
\hline
\end{tabular}

Ženklas $\check{\mathrm{z}}_{\mathrm{i}}(+(-))$ rodo, kad atitinkamai didesnè (mažesnè) kriterijaus reikšmè labiau atitinka suinteresuotos žmonių grupès reikalavimus. 
Daugiakriterinio nekilnojamojo turto vertinimo metodo esmè pateikta struktūrineje schemoje (2 pav.). Metodą sudaro dvylika etapu, iš jų du yra pradinių duomenų rinkimo ir tvarkymo etapai:

1 etapas. Faktorių, darančiu itaką nekilnojamojo turto rūšies objektų rinkos vertei, sistemos sudarymas. (plačiau apie tai 2 skyriuje).

2 etapas. Faktorių matavimo vienetu̧ reikšmių ir pradinių reikšmingumų nustatymas (2 pav.) (žr. 2 skyriu).

3 etapas. Sudaroma normalizuota sprendimu prièmimo matrica D. Šio etapo tikslas - iš lyginamų rodiklių gauti bedimensius įvertintus dydžius. Kai jie žinomi, visus skirting $\iota$ matavimo vienetų rodiklius galima palyginti pagal šią formulę:

$$
d_{i j}=\frac{x_{i j} \cdot q_{i}}{\sum_{j=1}^{n} x_{i j}}, \quad i=\overline{1, m} ; \quad j=\overline{1, n} .
$$

Kiekvieno kriterijaus $x_{i}$ gautų bedimensių ivertintų reikšmių $d_{i j}$ suma visada lygi šio kriterijaus reikšmingumui $q_{i}$ :

$$
q_{i j}=\sum_{j=1}^{n} d_{i j}, \quad i=\overline{1, m} ; \quad j=\overline{1, n}
$$

4 etapas. Apskaičiuojamos $j$ variantą apibūdinančių minimizuojanciu $S_{-j}$ ir maksimizuojančiu $S_{+j}$ jivertintų normalizuotú rodiklių sumos pagal formulę:

$$
S_{+j}=\sum_{i=1}^{m} d_{+i j} ; \quad S_{-j}=\sum_{i=1}^{m} d_{-i j} ; \quad i=\overline{1, m} ; \quad j=\overline{1, n}
$$

Šiuo atveju $S_{+j}$ ir $S_{-j}$ dydžiai išreiškia kiekvieno lyginamaisiais objektais pasiektų tikslų lygi.

Bet kuriuo atveju visų lyginamuju objektų pliusu $S_{+j}$ ir minusu $S_{-j}$ sumos visada yra atitinkamai lygios visoms maksimizuojančių ir minimizuojančiu kriteriju reikšmingumų sumoms:

$$
\begin{gathered}
S_{+j}=\sum_{j=1}^{n} S_{+j}=\sum_{i=1}^{m} \sum_{j=1}^{n} d_{+i j}, \\
S_{-j}=\sum_{j=1}^{n} S_{-j}=\sum_{i=1}^{m} \sum_{j=1}^{n} d_{-i j}, \\
i=\overline{1, m} ; \quad j=\overline{1, n} .
\end{gathered}
$$

5 etapas. Lyginamujų objektų santykinis reikšmingumas (efektyvumas) nustatomas remiantis juos apibūdinančiomis teigiamomis (+) $S_{+j}$ ir neigiamomis (-) $S_{-j}$ savybėmis. Kiekvieno varianto $a_{j}$ santykinis reikšmingumas $Q_{j}$ nustatomas pagal formulę:

$$
Q_{j}=S_{+j}+\frac{S_{-\min } \cdot \sum_{j=1}^{n} S_{-j}}{S_{-j} \cdot \sum_{j=1}^{n} \frac{S_{-\min }}{S_{-j}}}, j=\overline{1, n}
$$

6 etapas. Nustatomas objektı̨ prioritetiškumas. Juo didesnis $Q_{j}$, tuo didesnis varianto efektyvumas (prioritetiškumas). Apibendrintas kriterijus $Q_{j}$ tiesiogiai ir proporcingai priklauso nuo lyginamuju kriteriju reikšmiı $x_{i j}$ ir reikšmingumu $q_{i}$ santykinès ịtakos galutiniam rezultatui.

7 etapas. Nustatomas objekto $a_{j}$ naudingumo procentas $N_{j}$ pagal formulę:

$$
N_{j}=\frac{Q_{j}}{Q_{\max }} \cdot 100 \% .
$$

8 etapas. Nustatomas visų variantų $a_{j}$ efektyvumo lygis $E_{x j}$. Jis rodo, kiek procentı geresnis (blogesnis) objektas $a_{x}$, palyginti su objektu $a_{j}$ :

$$
E_{x j}=N_{x}-N_{j}, \quad j=\overline{1, n} .
$$

9 etapas. Nustatomas objekto $a_{x}$ naudingumo procento $N_{j}$ vidutinis nukrypimas $k_{x}$ :

$$
k_{x}=\sum_{j=1}^{n} E_{x j}:(\mathrm{n}-1)
$$

10 etapas. Jeigu 9-ame etape vertinamojo objekto naudingumo procento $N_{j}$ vidutinis nukrypimas $k_{x}$ neatitinka nelygybès:

$$
\left|k_{a x}\right|<1 \%
$$

tai pereinama prie 11 etapo.

11 etapas. Vertinamojo objekto vertès $V_{x p}$ patikslinimas pagal formulę:

$$
V_{x p}=C_{x}\left(1+k_{x}: 100\right)
$$

$V_{x p}$ - vertinamojo objekto patikslinta vertè; $C_{x}-$ patikslinta vertinamojo objekto vertè po n-ojo artejimo; $k_{x}$ - vertinamojo objekto naudingumo procento $N_{j}$ vidutinis nukrypimas po n-ojo artèjimo.

Vertinamojo objekto vertè tikslinama artejimo būdu, kol artejjimo ciklo vertinamojo objekto naudingumo procento vidutinis nukrypimas $k_{x}$ atitinka 9 nelygybę. Daugiakriterinio metodo 10 -ame etape atitikus 9 nelygybę, eina 12 metodo etapas. 


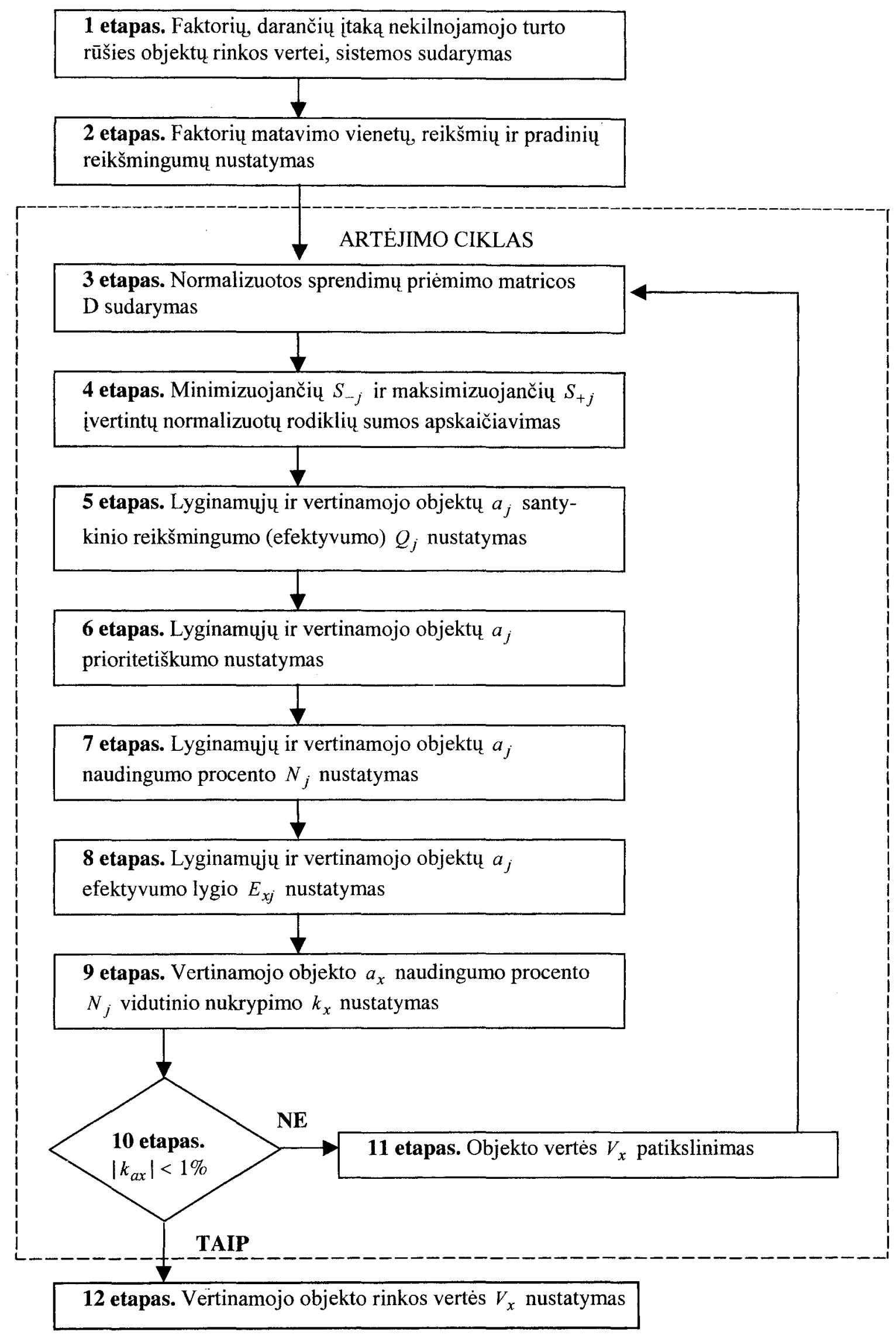

2 pav. Daugiakriterinio vertinimo metodo struktūrinè schema

Fig 2. Block diagram of multiple criteria valuation method 
12 etapas. Vertinamojo objekto rinkos vertès $V_{x}$ nustatymas pagal formulę:

$$
V_{x}=C_{x}\left(1+k_{x}: 100\right)
$$

$V_{x}$ - vertinamojo objekto rinkos verte; $C_{x}$ - patikslinta vertinamojo objekto vertè po n-ojo artejjimo; $k_{x}$ - vertinamojo objekto naudingumo procento $N_{j}$ vidutinis nukrypimas.

\section{Koncepcinis vertinamojo ir lyginamujų nekilnoja- mojo turto objekty̨ aprašymas}

Kad bütų lengviau suvokti daugiakriterinio vertinimo metodo esmę, pateikiamas jo taikymo pavyzdys. Uždavinys - nustatyti ūkininko sodybos rinkos vertę, esant lyginamuju ir vertinamojo objekto kiekybiniams, kokybiniams skirtumams, taip pat nustatyti vertinamojo objekto ir parduotu objektų (lyginamujų objektu) konkurenciškumą.

1996 m. rugsèjo mènesi nekilnojamojo turto rinkoje buvo siūloma parduoti žemès sklypa su gyvenamaisiais pastatais ükininko sodybai ikurti. Kliento pageidavimu minétą sklypą reikejjo ivertinti rinkos verte. Tuo metu nekilnojamojo turto rinka dar buvo neaktyvi, trūko rinkos duomeny (parduotų lyginamujų objektu), todèl lyginamieji objektai šiam vertinimui parinkti iš skirtingu rinkos konjunktūru. Rinkos konjunktūros suderintos loginiu ir ekonominiu aspektu. Šiuo atveju apskaičiuota lyginamoji vertẻ lygi rinkos vertei. Tiesioginiam palyginimui nebuvo analogu, todel ivertinti visi kriterijai, darantys itaką šios nekilnojamo turto rūšies rinkos vertei. Kriterijų reikšmès ir pradiniai reikšmingumai buvo ịvertinti padedant nekilnojamojo turto ekspertams ir atsižvelgiant $\mathfrak{i}$ turtu suinteresuotų asmenų nuomonę.

Kad lengviau būtų suprasti metodą, toliau pateikiamas to taikymo pavyzdys - ūkininko sodybos, esancios Šilales rajone, ivertinimas. Vertinamojo ir lyginamuju nekilnojamojo turto objektų koncepcinis aprašynıas pateiktas $4.1-4.3$ poskyriuose.

\subsection{Pirmosios (vertinamosios) ūkininko sodybos kon- cepcinis aprašymas}

Vietovès aprašymas. Žemès sklypas yra Pakarčemio kaime, Upynos seniūnijoje, Šilalès rajone. Iš dviejų pusių jis ribojasi ūkininkų sklypais, o iš trečios - su autostrada Kaunas - Klaipèda. Artimiausias socialinès ūkinès traukos centras yra už 3 km - Girdiškès. Upyna - už 7 km, rajono centras Šilalè - už $26 \mathrm{~km}$. Arti nèra rekreacinès zonos.

Žemès sklypo aprašymas. Visas žemès sklypas 15,19 ha, iš jų 12 ha - žemès ūkio naudmenos; 0,19 ha miškai; 0,7 ha - medžiai, krūmai, želdiniai; 0,9 ha - pelkès; 0,7 ha - keliai, iš jų bendro naudojimo - 0,5 ha; 0,5 ha - vandenys; 0,2 ha - užstatyta teritorija. Žemès sklype yra vienas gyvenamasis namas, tvartas ir lauko virtuvè, didelis sodas $(0,20 \mathrm{ha})$, du tvenkiniai $(0,50 \mathrm{ha})$, alksnių miškelis. Sklype teka šaltinis. Sodas - senas, bet yra nemaža ir jaunų medžių. Tvenkiniuose galima maudytis. Šalia ganyklos yra melioracijos griovys, kuriame galima girdyti gyvulius.

Pastatu fizinès charakteristikos. Visi mineti pastatai yra ikikarinès statybos. Gyvenamasis namas - medinis, iš rąstų, vieno aukšto, jam reikia rekonstrukcijos arba kapitalinio remonto. Tvartas - medinis, gerai išsilaikęs. Lauko virtuvè - plytu, taip pat gerai išsilaikiusi.

Patogumai. Visuose pastatuose yra elektra, kieme geras šulinys, teka šaltinis, kanalizacijos ir telefono nèra, gyvenamasis namas šildomas krosnimi.

Žemès fizinès charakteristikos. Kaip buvo mineta, žemès ūkio naudmenu plotas - 12,0 ha, iš jų: 7,7 ha ariamos žemès, 0,2 ha - sodas, 4,1 ha - pievos. Dalis žemès ūkio naudmenu yra nusausinta $-6,5$ ha. Žemès ūkio naudmenu našumo balas - 40. Žemè nenualinta, nuolat tręšiama ir dirbama. Sklypo konfigūracija patogi dirbti žemę, akmenuotumo nèra. Reljefas - lyguma. Pieva užsèta daugiametèmis žolèmis.

Apribojimai. Servitutų šiame sklype nèra. Yra apribojimu pagal LR Vyriausybès nutarimo Nr. 343 (redakcija 1640) XXI, XXIX ir XXVI skyrius [12] melioracinèms sistemoms bei irenginiams, vandens telkiniu apsaugos juostoms ir zonoms, privačių miškų tvarkymui ir naudojimui.

Žemès sklypo padeties elementai. Žemès sklypas yra strategiškai geroje vietoje, kadangi šalia eina autostrada Kaunas - Klaipeda. Be ūkininkavimo, galima užsiimti komercine veikla. Puikus susisiekimas su Kaunu, Klaipèda bei Kryžkalniu. Kryžkalnis yra už $12 \mathrm{~km}$, Šilalè - už 26 km. Artimiausia autobuso stotelè yra už $1 \mathrm{~km}$. Su socialinès ūkinès traukos centru - Girdiškèmis galima susisiekti žvyrkeliu - $3 \mathrm{~km}$. Kaimynai - ūkininkai, aplink laisvos valstybinès žemès nèra. Tarša ir triukšmas dideli dèl šalia einančios automagistralès. Žemès sklypas nèra prestižinèje vietoje. Pastatai yra šalia žvyrkelio ir vasaros metu dulkès kyla po langais. 
4.2. Antrosios ūkininko sodybos (lyginamojo objekto) koncepcinis aprašymas

Vietovés aprašymas. Žemès sklypas yra Akmeniu kaime, Aukštadvario seniūnijoje, Trakų rajone. Jis yra labai gražioje vietoje, prie Antakmenių ežero kranto (dalis ežero priklauso žemès sklypui) ir prie miško. Netoli sklypo yra ir kitas ežeras - Čiužiūnų. Netoli Aukštadvaris - už $5 \mathrm{~km}$, Trakai - už 25 km. Netoliese - Aukštadvario landšaftinis draustinis, istoriniai ir archeologiniai paminklai. Geras susisiekimas su Aukštadvariu (1 km žvyrkeliu).

Žemès sklypo aprašymas. Visas žemès sklypas 6,1 ha, iš jų žemés ükio naudmenos - 3,8 ha; miškai 0,9 ha; pelkès - 0,8 ha; vandenys - 0,2 ha (ežerai); užstatyta teritorija - 0,2 ha; kita žemè - 0,2 ha (nenaudojama). Šiame sklype yra gyvenamasis namas, tvartas, kluonas, lauko virtuvè ir pirtis, nedidelis sodas, dalis ežero $-0,2$ ha, lapuočių medžių miškelis (leidžiamas sanitarinis ir atrankinis kirtimas).

Pastaty fizinès charakteristikos. Visi minèti pastatai yra ikikarinès statybos. Gyvenamasis namas yra medinis, iš rąstų, $40 \mathrm{~m}^{2}$ ploto, gerai išsilaikęs (prieš 10 metų buvo atliktas kapitalinis remontas). Yra du kambariai ir virtuvè, atlikta visa vidaus apdaila, namas tinkamas gyventi. Tvartas - didelis, medinis, gerai išsilaikęs, tinkamas eksploatuoti. Kluonas - medinis, gerai išsilaikęs, tinkamas eksploatuoti. Lauko virtuvè - medinè, joje irengta pirtis, tinkama naudoti. Yra geras rūsys.

Patogumai. Visuose kapitaliniuose pastatuose yra elektra, šildoma krosnimi, kieme - šulinys, iš ežero i tvartą nutiestas vandentiekis, yra galimybè isivesti telefoną.

Žemès fizinès charakteristikos. Žemès ūkio naudmenos $-3,8$ ha, iš jų: ariama žemè $-0,9$ ha, pievos $-2,9$ ha. Žemè nemelioruota, žemès ūkio naudmenų našumo balas - 34. Žemé nenualinta, nuolat tręšiama ir dirbama. Vietovè kalvota, sklypo konfigüracija nepatogi žemei dirbti, akmenuotumo nèra.

Apribojimai. Servitutu šiame sklype nèra. Apribojimai sklype nustatyti pagal LR Vyriausybès nutarimo Nr. 343 (redakcija 1640) XXIX skyriu [12] dèl vandens telkiniu pakrantès apsaugos juostos, apribojamas plotas 0,07 ha.

Žemès sklypo padèties elementai. Privažiavimas prie žemès sklypo yra nuo Aukštadvario asfaltu $-4 \mathrm{~km}$ ir žvyrkeliu $-1 \mathrm{~km}$. Atstumas iki rajono centro $-25 \mathrm{~km}$
(Traku). Strateginè žemės sklypo padètis yra gera, geras susisiekimas, netoli Vilnius, sklypas egzotiškoje vietoje, yra galimybè plèsti ūki, nes šalia yra laisvos valstybinès žemès. Aplinkos užterštumo ir triukšmo nėra, žemès sklypas yra prestižiniame rajone.

\section{Žemés sklypo pardavimo kaina $-40000 \mathrm{Lt}$.}

\subsection{Trečiosios ūkininko sodybos (lyginamojo objekto) koncepcinis aprašymas}

Vietovès aprašymas. Žemès sklypas yra Šilènu kaime, Sangrūdos seniūnijoje, Marijampolès rajone. Artimiausias socialinès ūkinès traukos centras yra Mockava - 3 km, Sangrūda - 6 km, Kalvarijos - 13 km, Lazdijai $13 \mathrm{~km}$, rajono centras Marijampolè - už 24 km. Arti rekreacinès zonos nèra.

Žemès sklypo aprašymas. Visas žemès sklypas 9,52 ha, iš ju žemès ükio naudmenos $-6,14$ ha; medžiai, krūmai, želdiniai - 0,4 ha; vandenys - 0,4 ha; užstatyta teritorija $-0,4$ ha; kita žemè $-2,4$ ha nenaudojama. Žemès sklype yra vienas gyvenamasis namas, tvartas, kluonas, virtuvė, labai didelis sodas $-0,6$ ha. Žemès sklypu teka upelis.

Pastatu fizinès charakteristikos. Visi minèti pastatai yra pokarinès statybos - $1945 \mathrm{~m}$. Gyvenamasis namas yra dviejų galų -- $80 \mathrm{~m}^{2}$, medinis, iš rąstų, gerai išsilaikęs, tinkamas gyventi. Tvartas, kluonas ir lauko virtuvè mediniai, gerai išsilaikę, tinkami eksploatuoti.

Patogumai. Visuose pastatuose yra elektra, kieme geras šulinys, kanalizacijos nèra, šildoma - krosnimi, telefono nèra.

Žemès fizinès charakteristikos. Kaip buvo minèta, žemès ükio naudmenu plotas $-6,14$ ha, iš jụ: ariama žemè $-5,5$ ha, sodas $-0,6$ ha, pievos $-0,04$ ha. Žemé nenusausinta ir nedrèkinama (nėra drenažo), naudmenu našumo balas $-25,1$. Žemè nenualinta, nuolat tręšiama ir dirbama. Reljefas - lyguma, palankus žemei dirbti. Slypo konfigūracija - stačiakampis.

Apribojimai. Servitutu nèra. Apribojimas yra vandens telkiniu pakrantès apsaugos juostai pagal LR Vyriausybès nutarimo Nr. 343 (redakcija 1640) XXIX skyriu [12], apribojamas plotas $-0,04$ ha.

Žemès sklypo padèties elementai. Privažiavimas prie sodybos gruntiniu keliu (1 km). Sklypo riba sutampa su Lazdiju rajono riba, t. y. žemès sklypas yra Marijampolès rajono pakraštyje. Aplink sklypa yra laisvos valstybinès žemès, t. y. galimybè plèsti ūkị. Užterštumo ir 
triukšmo nèra. Žemès sklypas nèra prestižinèje vietoje, bet patrauklus - šalia gražūs pavieniai ą̌̌uolai, aplinkui daug erdvès.

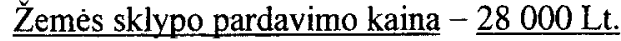

\section{Pateikto uždavinio sprendimas}

\subsection{Sprendimo priẻmimo matricos sudarymas}

Remiantis pateiktu ükininkų sodybų koncepciniu aprašymu ir 2 skyriuje pateiktomis rekomendacijomis buvo sudaryta sprendimo prièmimo matrica (2 lent.).

Šioje matricoje reikèjo nustatyti vertinamojo objekto, esančio Šilalès rajone, rinkos vertę ir kompleksiškai ivertinti vertinamojo ir lyginamuju objektu teigiamas ir neigiamas savybes. Lyginamieji objektai, esantys Trakų ir Marijampolès rajonuose, buvo parduoti ir ju pardavimo kainos buvo žinomos ( 2 lent.).

Kriterijų sistema sudaryta atsižvelgiant $\mathfrak{i}$ visus galimus kriterijus, apibūdinančius vertinamojo ir lyginamuju objektų kokybines, kiekybines savybes. Kokybinių kriterijų reikšmès ir reikšmingumai nustatyti ekspertiniu būdu, apklausiant rinkos dalyvius, t. y. vertintojus-ekspertus, pirkejus ir pardavejus. Lyginamuju objektų pardavimo kainos yra nepaaukštintos ir nesumažintos del rinkos dalyvių asmeniškumo ir kitų nenumatytu aplinkybių. Galima teigti, kad visi kriterijai, turintys itakos tiriamo turto rūšies rinkos vertei, yra numatyti. Lyginamujų objektu pardavimo laikas sutampa su vertinamojo objekto pardavimo laiku, todèl ị laiko pataisos koeficientą nebuvo atsižvelgta. Pardavimo kainos kriterijaus reikšmingumas buvo imtas lygus visı̨ kitų turinčių itakos rinkos vertei kriterijų reikšmingumų sumai.

Sprendimo prièmimo matricoje kiekybinių kriteriju, pavyzdžiui, lyginamujų objektu pardavimo kaina, sklypo užstatymo plotas, pagalbinių pastatų skaičius, gyvenamojo pastato bendrasis plotas, matavimo vienetai buvo nustatyti kiekybiniais dydžiais: litais, hektarais, vienetais, kvadratiniais metrais, o kokybiniai kriterijai buvo matuojami balais, kurie nustatyti išrenkant konkretaus objekto geriausią reikšmę, o kitiems suteikiant santykines reikšmes. Pavyzdžiui, žemès sklypas, pagal konfigūraciją labiausiai tinkantis dirbti žemès ükio darbus, yra Marijampolès rajone (lyginamasis objektas), todèl jam buvo suteikta kriterijaus geriausia reikšmè - 1 , o vertinamajam objektui - prastesnè reikšmè, kuri lygi 0,93 , nes jis nèra toks patogus kaip žemès sklypas, esantis Marijampolès rajone, o lyginamajam objektui, esančiam Trakų rajone, santykinai dar mažesnè - 0,87 . Kriterijų, apibūdinančių itaką objekto vertei, reikšmingumai buvo taip pat nustatyti ekspertiniu būdu, pavyzdžiui, didžiausią ittaką nagrinèjamos paskirties objektu (ūkininko sodyboms) rinkos vertei turi gyvenamojo pastato buvimas žemès sklype, kuriam suteiktas kriterijaus reikšmingumas lygus 0,50 (2 lent.).

\subsection{Pirmo artèjimo skaičiavimo rezultatai}

Pirmame artejimo cikle vertinamojo objekto pradinè vertè buvo prilyginta lyginamujų objektų pardavimo kainų vidurkiui, t. y. 34000 Lt (2 lent.).

Sudarius faktorių sistemą ir nustačius jų reikšmes bei reikšmingumus, buvo parengta sugrupuota sprendimų prièmimo matrica (2 lent.). Remiantis šia matrica, pagal (1) formulę buvo skaičiuoti faktorių reikšmingumai (3 lent.):

$$
\begin{aligned}
& d_{11}=34,00 \cdot 7,99 /(34,0+40,0+28,0)=2,6633 \\
& d_{12}=40,00 \cdot 7,99 /(34,0+40,0+28,0)=3,1333 \\
& d_{13}=28,00 \cdot 7,99 /(34,0+40,0+28,0)=2,1933 \\
& d_{21}=0,20 \cdot 0,25 /(0,2+0,2+0,4)=0,0625 \\
& d_{22}=0,20 \cdot 0,25 /(0,2+0,2+0,4)=0,0625 \\
& d_{23}=0,40 \cdot 0,25 /(0,2+0,2+0,4)=0,125 \\
& d_{31}=12,00 \cdot 0,50 /(12,0+3,8+6,14)=0,2735 \\
& d_{32}=3,80 \cdot 0,50 /(12,0+3,8+6,14)=0,0866 \\
& d_{33}=6,14 \cdot 0,50 /(12,0+3,8+6,14)=0,1399
\end{aligned}
$$

Kiekvieno kriterijaus gautu bedimensių ivertintų reikšmių $d_{i j}$ suma visada lygi šio kriterijaus reikšmingumui, pavyzdžiui, sklypo užstatymo ploto kriterijus apskaičiuojamas pagal (2) formulę:

$$
q_{2}=\sum_{j=1}^{n} d_{2 j}=0,0625+0,0625+0,1250=0,250 .
$$

Vertinant buvo nustatyta, kad didžiausią ịtaką tiriamo nekilnojamojo turto rū̌ies (ūkininko sodyba) rinkos vertei turi šie veiksniai: gyvenamojo namo buvimas sodyboje ir dirbamos žemès plotas $\left(\boldsymbol{q}_{3}=\mathbf{0 , 5 0}, \boldsymbol{q}_{7}=\mathbf{0 , 5 0}\right)$; gyvenamujų pastatų kompleksinis ivertinimas, pagalbinių (ūkinių pastatu) skaičius, jų bendrasis plotas ir kompleksinis ìvertinimas bei žemès ūkio naudmenu našumas arba santykinis derlingumas $\left(q_{9}=0,45, q_{11}=0,45, q_{12}=0,45\right.$, $q_{14}=\mathbf{0 , 4 5}$ ).

Vèliau buvo apskaičiuotos lyginamuosius ir vertinamaji objektus apibüdinančiu minimizuojančių $S_{-j}$ ir 
2 lentelè. Pradiniai duomenys ūkininko sodybos daugiakriteriniam ịvertinimui

Table 2. Initial data of multiple criteria valuation of a farmer's estate

\begin{tabular}{|c|c|c|c|c|c|c|}
\hline \multirow[t]{2}{*}{ Nagrinèjami kriterijai } & \multirow[t]{2}{*}{$*$} & \multirow[t]{2}{*}{$\begin{array}{c}\text { Kriterijaus } \\
\text { matavimo } \\
\text { vienetas }\end{array}$} & \multirow[t]{2}{*}{$\begin{array}{l}\text { Kriterijaus } \\
\text { reikšmin- } \\
\text { gumas }\end{array}$} & $\begin{array}{c}\text { Vertinamoji } \\
\text { ukininko } \\
\text { sodyba }\end{array}$ & \multicolumn{2}{|c|}{$\begin{array}{l}\text { Lyginamosios üki- } \\
\text { ninko sodybos }\end{array}$} \\
\hline & & & & Šilales $r$. & $\begin{array}{l}\text { Traku } \\
\text { r. }\end{array}$ & $\begin{array}{l}\text { Marijam- } \\
\text { polès } r \text {. }\end{array}$ \\
\hline 1. Pardavimo kaina (pradiné vertè) & - & Lt (tūkst.) & 7,99 & $\mathrm{X}$ & 40,0 & 28,0 \\
\hline Žemès sklypo kiekybinis jivertinimas & & & & & & \\
\hline 2. Sklypo užstatymo plotas & + & ha & 0,25 & 0,20 & 0,20 & 0,40 \\
\hline 3. Ariamosios, ganyklos plotas & + & ha & 0,50 & 12,00 & 3,80 & 6,14 \\
\hline 4. Sodo plotas & + & ha & 0,20 & 0,20 & 0,00 & 0,60 \\
\hline 5. Vandenų plotas & + & ha & 0,15 & 0,50 & 0,20 & 0,40 \\
\hline 6. Mišku plotas & + & ha & 0,22 & 0,19 & 0,90 & 0,00 \\
\hline Pastatų ivertinimas & & & & & & \\
\hline 7. Gyvenamieji pastatai (skaičius) & + & vnt. & 0,50 & 1,00 & 1,00 & 1,00 \\
\hline 8. Gyvenamuju pastaty bendrasis plotas & + & $\mathrm{m}^{2}$ & 0,35 & 35,00 & 40,0 & 80,0 \\
\hline 9. Gyvenamuju pastatų kompleksinis ịvertinimas & + & balai & 0,45 & 0,47 & 0,82 & 1,00 \\
\hline 10. Pagalbiniu pastatų skaičius & + & vnt. & 0,40 & 2,00 & 3,00 & 3,00 \\
\hline 11. Pagalbinių pastatų bendrasis plotas & + & $\mathrm{m}^{2}$ & 0,45 & 60,00 & 300 & 220 \\
\hline 12. Pagalbinių pastatų kompleksinis jvertinimas & + & balai & 0,45 & 0,84 & 1,00 & 0,89 \\
\hline Žemès sklypo kokybinis ivertinimas & & & & & & \\
\hline $\begin{array}{l}\text { 13. Žemés sklypo konfigūracija ir patogumas dirbti žemès } \\
\text { ùkio darbus }\end{array}$ & + & balai & 0,25 & 0,93 & 0,87 & 1,00 \\
\hline $\begin{array}{l}\text { 14. Žemés ūkio naudmenų našumas arba santykinis der- } \\
\text { lingumas }\end{array}$ & + & balai & 0,45 & 1,00 & 0,85 & 0,63 \\
\hline 15. Žemès nualinimas & - & balai & 0,12 & 0,09 & 0,12 & 0,05 \\
\hline 16. Reljefas ir apdirbimo sunkumas & - & balai & 0,10 & 0,11 & 0,15 & 0,00 \\
\hline Žemès sklypo apribojimai & & & & & & \\
\hline 17. Žemès servitutai ir žemès naudojimo apribojimai & - & balai & 0,15 & 0,14 & 0,11 & 0,08 \\
\hline Infrastruktūros ivertinimas & & & & & & \\
\hline 18. Energijus tiekimo ivertinimas & + & balai & 0,30 & 1,00 & 1,00 & 1,00 \\
\hline 19. Vandentiekio juertinimas & + & balai & 0,30 & 1,00 & 0,95 & 0,88 \\
\hline 20. Kanalizacijos ivertinimas & + & balai & 0,30 & 0,05 & 0,10 & 0,15 \\
\hline 21. Telefono paslaugu ivertinimas & + & balai & 0,15 & 0,03 & 1,00 & 0,33 \\
\hline 22. Apšildymo juertinimas & + & balai & 0,30 & 0,96 & 1,00 & 0,89 \\
\hline Kiti kriterijai & & & & & & \\
\hline 23. Žemès sklypo teritorinis išsidestymas & & & & & & \\
\hline - produkcijos isigijimo ir realizavimo punktų atžvilgiu & & & & & & \\
\hline $\begin{array}{l}\text { - socialinio, kultūrinio, buitinio aptarnavimo objektų } \\
\text { atžvilgiu }\end{array}$ & + & balai & 0,40 & 0,52 & 1,00 & 0,49 \\
\hline 24. Kaimynystėje esantys potencialūs pirkèjai ir pardavejjai & + & balai & 0,10 & 0,26 & 1,00 & 1,00 \\
\hline 25. Galimybè panaudoti žemès sklypą kitai veiklai & + & balai & 0,30 & 0,66 & 0,33 & 0,15 \\
\hline 26. Oro, aplinkos užterštumo ir triukšmo lygis & + & balai & 0,15 & 0,22 & 1,00 & 1,00 \\
\hline 27. Žemès sklypo patrauklumas & + & balai & 0,15 & 0,35 & 1,00 & 1,00 \\
\hline 28. Vietovès prestižas & + & balai & 0,15 & 0,12 & 1,00 & 0,18 \\
\hline 29. Rinkos konjunktūros ivertinimas & + & balai & 0,40 & 0,05 & 0,15 & 0,10 \\
\hline
\end{tabular}

* + (-) rodo, kad atitinkamai didesnè (mažesnè) kriterijaus reikšmè labiau atitinka suinteresuotos žmonių grupès reikalavimus. 
maksimizuojančiu $S_{+j}$ ivertintų normalizuotų rodiklių sumos pagal (3) formulę:

$$
\begin{gathered}
S_{-1}=2,6633+0,0415+0,0423+ \\
+0,0636=2,8107 ; \\
S_{+1}=2,1063 ; S_{-2}=3,2964 ; S_{+2}=2,9091 ; \\
S_{-3}=2,2528 ; \quad S_{+3}=2,6034 .
\end{gathered}
$$

Šiuo atveju $S_{+j}$ ir $S_{-j}$ dydžiai išreiškia lyginamaisiais objektais pasiektų tikslų lygi.

Bet kuriuo atveju visų lyginamuju objektų pliusų $S_{+j}$ ir minusu $S_{-j}$ sumos visada yra atitinkamai lygios visoms maksimizuojančiu ir minimizuojančiu kriteriju reikšmingumų sumoms pagal (4) formulę:

$$
\begin{gathered}
S_{-}=2,6633+3,1333+2,1933+0,0415+ \\
+0,0554+0,0231+0,0423+0,0577+0,0636+ \\
+0,05+0,0364=8,3599 \\
S_{+}=7,6188 .
\end{gathered}
$$

Vèliau, remiantis (5) formule, nustatytas kiekvieno lyginamojo ir vertinamojo objektų santykinis reikšmingumas:

$$
\begin{gathered}
Q_{1}=2,1063+ \\
+\frac{2,2528 \cdot(2,8107+3,2964+2,2528)}{2,8107 \cdot\left(\frac{2,2528}{2,8107}+\frac{2,2528}{3,2964}+\frac{2,2528}{2,2528}\right)}= \\
=4,8028 \\
Q_{2}=5,2083 ; \quad Q_{3}=5,9678
\end{gathered}
$$

Pirmame artejimo cikle, remiantis (6) formule, kaip naudingiausias pagal naudojimo paskirti buvo ivertintas lyginamasis objektas, esantis Marijampolès rajone: $\mathrm{N}_{3}$ $=100 \%$, antras pagal naudinguma - lyginamasis objektas, esantis Traku rajone $N_{2}=87,27 \%$, ir trečias - vertinamasis objektas, esantis Šilalès rajone (3 lent.). Vèliau buvo nustatytas lyginamuju ir vertinamojo objekty efektyvumo lygis $E_{x j}((7)$ formule). Jis rodo, kiek procentų geresnis (blogesnis) vertinamasis objektas, palyginti su lyginamaisiais, ir lyginami tarpusavyje.

Pavyzdžiui:

$$
\begin{gathered}
E_{11}=80,48 \%-80,48 \%=0,000 \% ; \\
E_{12}=80,48 \%-87,27 \%=-6,79 \% ; \\
E_{13}=80,48 \%-100,0 \%=-19,52 \% ; \\
E_{21}=6,79 \% ; \quad E_{22}=0,000 \% ; \quad E_{23}=-12,73 \% ; \\
E_{31}=19,52 \% ; \quad E_{32}=12,73 \% ; \quad E_{33}=0,000 \%
\end{gathered}
$$

Vèliau, remiantis (8) formule, buvo apskaičiuotas vertinamojo objekto naudingumo procento vidutinis nukrypimas $k_{x}$, nuo kurio ir priklauso, ar kitu etapu iškart bus nustatoma vertinamojo objekto rinkos vertè, ar bus tik patikslinta pradiné vertè ir kartojamas artèjimo ciklas. Po pirmo artejjimo vertinamo objekto naudingumo procento vidutinis nukrypimas $k_{x}$ neatitiko (9) nelygybès, gautas toks rezultatas:

$$
k_{a x}=|-13,16|>1 \text {. }
$$

Tuomet, remiantis (10) formule, buvo patikslinta vertinamojo objekto vertè :

$$
V_{1}=34000(1-13,16 / 100)=29525,6 \text { Lt. }
$$

Patikslinus vertinamojo objekto vertę, pagal metodo struktūrinę schemą ( 2 pav.) toliau eina metodo artejimo ciklas.

\subsection{Galutiniai rezultatai}

Kaip matome iš 3 lentelès, pirmame artejjimo cikle naudingiausias pagal naudojimo paskirti yra lyginamasis objektas, esantis Marijampolès rajone $\left(N_{3}==100 \%\right.$ ), antras pagal naudingumą - lyginamasis objektas, esantis Traky rajone $\left(N_{2}=87,27 \%\right)$, ir trečiasis - vertinamasis objektas, esantis Šilalès rajone $\left(N_{1}=80,48 \%\right)$. Kaip matome iš apskaičiuotų objektų naudingumo procento, vertinamosios ūkininko sodybos Šilales rajone pradinè verte $x=34000 \mathrm{Lt}$ yra per didelè, dèl to šis objektas nèra vienodai konkurencingas rinkoje, palyginti su ūkininku sodybomis Trakų ir Marijampolès rajonuose, kompleksiškai ivertinus ju teigiamas ir neigiamas savybes. Tą patvirtina ir nelygybej $k_{a x}=|-13,16|>1 \%$. Remiantis šia nelygybe buvo nustatyta, kad dar nepakankamai tiksliai apskaičiuota vertinamosios ūkininko sodybos Šilalès rajone vertè.

Todel, remiantis vertinamojo nekilnojamojo turto objekto rinkos vertès skaičiavimo struktūrine schema, pateikta (2 pav.), skaičiavimų ciklai buvo tęsiami tol, kol vertinamojo objekto naudingumo procento vidutinis nukrypimas atitiko nelygybę $\left|k_{a x}\right|<1 \%$.

Šių skaiciavimų ciklų rezultatas - vertinamosios ūkininko sodybos Šilalès rajone patikslintos vertès kitimas ir rinkos vertès nustatymas - pateiktas 4 lentelèje.

Kaip matome, pirmus 4 ciklus vertinamojo objekto naudingumo procento vidutinis nukrypimas neatitiko nelygybès $\left|k_{a x}\right|<1 \%$. Todèl 4 kartus patikslinta vertinamojo objekto vertè $V_{x p}$ (atitinkamai $29526 \mathrm{Lt}, 27445 \mathrm{Lt}$, $26447 \mathrm{Lt}, 25955 \mathrm{Lt}$ ) buvo itraukiama i nekilnojamojo 
3 lentelé. Ūkininku sodybų daugiakriterinès analizès rezultatai ( 1 artẻjimo ciklas, $X=34000$ )

Table 3. Farmer estates valuation results obtained by multiple criteria analysis (1-st approximation cycle, $X=34000$ )

\begin{tabular}{|c|c|c|c|c|}
\hline \multirow[t]{2}{*}{ Nagrinèjami kriterijai } & \multirow[t]{2}{*}{ * } & \multicolumn{3}{|c|}{$\begin{array}{l}\text { Ũkininko sodybos (normalizuotu ivertintų kriteriju } \\
\text { skaitmeninès reikšmés } d_{i j} \text { ) }\end{array}$} \\
\hline & & Šilalès r. & Traku r. & Marijampolès $r$. \\
\hline 1. Pardavimo kaina (rinkos vertè) & - & 2,6633 & 3,1333 & 2,1933 \\
\hline 2. Sklypo užstatymo plotas & + & 0,0625 & 0,0625 & 9,1250 \\
\hline 3. Ariamosios, ganyklos plotas & + & 0,2735 & 0,0866 & 0,1399 \\
\hline 4. Sodo plotas & + & 0,0500 & 0,0000 & 0,1500 \\
\hline 5. Vandenu plotas & + & 0,0680 & 0,0273 & 0,0545 \\
\hline 6. Misku plotas & + & 0,0383 & 0,1816 & 0,0000 \\
\hline 7. Gyvenamieji pastatai (skaičius) & + & 0,1666 & 0,1666 & 0,1666 \\
\hline 8. Gyvenamuju pastatu bendrasis plotas & + & 0,0790 & 0,0903 & 0,1806 \\
\hline 9. Gyvenamuju pastaty kompleksinis ivertinimas & + & 0,0924 & 0,1612 & 0,1965 \\
\hline 10. Pagalbiniu pastatu skaicius & + & 0,1000 & 0,1500 & 0,1500 \\
\hline 11. Pagalbiniu pastatu bendrasis plotas & + & 0,0465 & 0,2328 & 0,1707 \\
\hline 12. Pagalbiniч pastatu kompleksinis ivertinimas & + & 0,1385 & 0,1648 & 0,1467 \\
\hline $\begin{array}{l}\text { 13. Žemès sklypo konfigūracija ir patogumas dirbti žemès ūkio } \\
\text { darbus }\end{array}$ & + & 0,0830 & 0,0776 & 0,0893 \\
\hline 14. Žemès ūkio naudmenu našumas arba santykinis derlingumas & + & 0,1814 & 0,1542 & 0,1143 \\
\hline 15. Žemès nualinimas & - & 0,0415 & 0,0554 & 0,0231 \\
\hline 16. Reljefas ir apdirbimo sunkumas & - & 0,0423 & 0,0577 & 0,0000 \\
\hline 17. Žemès servitutai ir žemès naudojimo apribojimai & $\cdot$ & 0,0636 & 0,0500 & 0,0364 \\
\hline 18. Energijos tiekimo ivertinimas & + & 0,1000 & 0,1000 & 0,1000 \\
\hline 19. Vandentiekio ivertinimas & + & 0,1060 & 0,1007 & 0,0933 \\
\hline 20. Kanalizacijos ivertinimas & + & 0,0500 & 0,1000 & 0,1500 \\
\hline 21. Telefono paslaugy ivertinimas & + & 0,0276 & 0,0920 & 0,0304 \\
\hline 22. Apsildymo ivertinimas & + & 0,1010 & 0,1053 & 0,0937 \\
\hline 23. Žemès sklypo teritorinis išsidèstymas & & & & \\
\hline - produkcijos isigijimo ir realizavimo punktų atžvilgiu & & & & \\
\hline - socialinio, kultürinio, buitinio aptarnavimo objektų atžvilgiu & + & 0,1035 & 0,1990 & 0,0975 \\
\hline 24. Kaimynystèje esantys potencialūs pirkèjai ir pardavèjai & + & 0,0115 & 0,0442 & 0,0442 \\
\hline 25. Galimybè panaudoti Žemès sklypą kitai veiklai & + & 0,1094 & 0,1657 & 0,0248 \\
\hline 26. Oro, aplinkos užterštumo ir triukšmo lygis & + & 0,0148 & 0,0675 & 0,0675 \\
\hline 27. Žemès sklypo patrauklumas & + & 0,0223 & 0,0638 & 0,0638 \\
\hline 28. Vietovès prestižas & + & 0,0138 & 0,1154 & 0,0208 \\
\hline 29. Rinkos konjunktūros ivertinimas & + & 0,0667 & 0,2000 & 0,1333 \\
\hline Maksimizuojanciu normalizuoty ivertinimy rodikliu suma $S_{+j}$ & & 2,1063 & 2,9091 & 2,6034 \\
\hline Minimizuojanxiy̨ normalizuoty ivertinimų rodiklių suma $S_{-j}$ & & 2,8107 & 3,2964 & 2,2528 \\
\hline Nekilnojamojo turto objektų reikšmingumas $Q_{j}$ & & 4,8028 & 5,2083 & 5,9678 \\
\hline Nekilnojamojo turto objektų prioritetas & & 3 & 2 & 1 \\
\hline Nekilnojamojo turto objekty naudingumo procentas $N_{j}$ & & $80,48 \%$ & $87,27 \%$ & $100 \%$ \\
\hline Nekilnojamojo turto objektų konkurenciškumas $k_{x}$ & & $-13,16 \%$ & $-2,97 \%$ & $+16,12 \%$ \\
\hline Vertinamojo objekto patikslinta verte $V_{x p}$ & & $29525,6 \mathrm{Lt}$ & & \\
\hline
\end{tabular}

${ }^{*}+(-)$ rodo, kad atitinkamai didesnè (mažesnè) kriterijaus reikšmè labiau atitinka suinteresuotos žmonių grupès reikalavimus. 
4 lentelè. Vertinamojo objekto naudingumo lygio vidutinio nukrypimo ir patikslintos vertès kitimas bei rinkos vertes nustatymas

Table 4. Determining the average deviation of utility and market value of an object valuated; variation of corrected value

\begin{tabular}{|c|c|c|c|}
\hline Artèjimo ciklas & $\begin{array}{c}\text { Vertinamojo objekto patikslinta } \\
\text { vertè } V_{x p}(\mathrm{Lt})\end{array}$ & $\begin{array}{c}\text { Vertinamojo objekto naudingumo } \\
\text { lygio vidutinis nukrypimas } k_{x} \\
(\%)\end{array}$ & $\begin{array}{c}\text { Vertinamojo objekto rinkos } \\
\text { vertè } V_{x}(\mathrm{Lt})\end{array}$ \\
\hline 1 & 34000 & $|-13,16|>1$ & \\
2 & 29526 & $|-7,03|>1$ & \\
3 & 27445 & $|-3,64|>1$ & \\
4 & 26447 & $|-1,86|>1$ & \\
5 & 25955 & $|-0,94|<1$ & $25955(1-0,94: 100)=\mathbf{2 5} \mathbf{7 0 0}$ \\
\hline
\end{tabular}

turto objektu daugiakriterinès analizès sprendimu prièmimo matricą (2 lent.). Visi skaixiavimai pagal (1-9) formules buvo kartojami iki tol, kol penktajame cikle vertinamojo objekto naudingumo procento vidutinis nukrypimas atitiko nelygybę $\left|k_{a x}\right|<1 \%$.

Kaip matome iš 4 lentelès, kiekviename kitame artèjimo cikle vis tiksliau buvo apskaičiuojama vertinamojo objekto vertè. Paskutiniame, penktame cikle vertinamojo objekto naudingumas lyginamujų objektų atžvilgiu nustatytas $N_{1}=93,22 \%$, lyginamojo objekto, esančio Traku rajone, $-N_{2}=88,32 \%$, o kito lyginamojo objekto, esančio Marijampoles rajone, liko nepakitęs per visus priartéjimo ciklus $-N_{3}=100 \%$. Apskaičiuoti objektų naudingumo procentai rodo, kad vertinamasis objektas yra $4,9 \%$ naudingesnis už lyginamaji objekta, esanti Trakų rajone, ir 6,78 \% mažiau naudingas už lyginamaji objekta, esanti Marijampolès rajone. Šie skaičiai parodo, ì kuri objektą labiau apsimoka investuoti pinigus.

\section{Siūlomo metodo privalumai}

1. Daugiakriteriniu vertinimo metodu turtą gali vertinti visos turtu suinteresuotos grupès (rinkos dalyviai) siekdami patenkinti savo poreikius. Pavyzdžiui, investuotojas vertina turta geriausio ir naudingiausio panaudojimo atžvilgiu, nekilnojamojo turto vertintojas - rinkos situacijos atžvilgiu ir pan. Vertinant turtą skirtingais požiūriais, skirsis ir tai vertei daranti ịtaką kriterijų sistema, jų pradinès reikšmès bei reikšmingumai.

2. Daugiakriterinis vertinimo metodas yra vienas iš dedukcinių nekilnojamojo turto vertinimo metodu, tinkančiu nustatyti nekilnojamojo turto rinkos vertę bei atlikti turto kompleksinę analizę.

3. Taikant šiame straipsnyje pateiktą metoda, lyginamieji objektai vertinamajam gali būti parinkti iš skirtin- gu rinkos konjunktūrų. Šis metodas taikytinas aktyvioje ir neaktyvioje rinkose.

4. Daugiakriterinis vertinimo metodas yra taikytinas nekilnojamojo turto analizei: nustatyti objektų naudingumą, prioritetiškumą vienas kito atžvilgiu, faktoriub lemiančių nekilnojamojo turto vertę, reikšmingumus, parduotų objektų ir vertinamojo objekto konkurenciškumą. Šis metodas tinka ir atliekant pasiülos analizę, kuria remiantis galima iš pasiūloje esančių objektu išrinkti geriausiai ir efektyviausiai specifinès objekto rūšies panaudojimą atitinkanti variantą

5. Taikant ši metoda praktiškai, firmos galetų išplèsti savo paslaugu mastą, kartu padidètų šiu paslaugu paklausa ir prestižas.

\section{Literatüra}

1. H. E. Auernhammer. Die Zielbaum-Methode als Hilfsmittel zur Lösung von Bewertungsproblemen in der Systemtechnik. Stuttgart, 1976.219 S.

2. K. Gablenz. Verkehrswertermittlung von landwirtschaftlichen Grundstücken. Handbuch mit Erlaüterungen, Praxisbeispielen und Hinweisen für den Er bfall.1 Auflage, Bundesanzeiger Verlagsges. MbH. Koeln, 1998. 276 S.

3. B Bischof. Grundstückswerte in den neuen Bundesländern: wie sich ungeklärte Eigentumsfragen auf Verkehrswerte auswirken. 2 Auflage. Berlin Verlag Axno Spitz GmbH, 1996. $663 \mathrm{~S}$.

4. R. Vogel. Zur Ermittlung von Grundstückswerten (Bodenpreisen) in der DDR. Der Sachverständige, Verlag Recht und Wirtschaft Heidelberg, 1990, H. 9. $200 \mathrm{~S}$.

5. G. Sommer, P. Zimmermann. Bestimmung von Bodenwerten in den neuen Bundesländern // Zeitschrift GUG 4/1991, S. 193-204.

6. Sommer/Piehler. Grundstücks und Gebaüde- Wertermittlung für die Praxis. Herausgeber: Haufe Orga-Handbuch, 1996. $208 \mathrm{~S}$.

7. T. Gerardy, R. Moeckel. Methoden der vorlaeufigen Bewertung von Grund und Boden // Praxis der Grundstuecksbewertung. 1. Nachlieferung, Band 1, Verlag moderne Industrie, 10/1991, 9.4/3-9.4/6. 1991. 
8. D. Kertscher. Wertermittlungspraxis in den neuen Bundesländern // Veranstaltung Nr. 11, Grundstiuckswertermittlung, Wildeshausen, 1993, S. 10-31.

9. E. K. Zavadskas, F. Peldschus, A. Kaklauskas. Multiple Criteria Evaluation of Projects in Construction. V.: Technika, 1994. $226 \mathrm{p}$.

10. E. K. Zavadskas, A. Kaklauskas. Pastatų sistemotechninis juertinimas. V.: Technika, 1996. $279 \mathrm{p}$.

11. E. Zavadskas, A. Kaklauskas, V. Malienè. Real Estate Price Evaluation by Means of Multicriteria Project Assessment Methods // Property Valuation and Investment in Central and Eastern Europe during the Transition to Free Market Economy. V.: Technika, 1997, p. 156-170.

12. Lietuvos Respublikos Vyriausybès 19951229 nutarimas Nr. 1640 „Dèl Lietuvos Respublikos Vyriausybès 199205 12 nutarimo Nr. 343 „Dèl Specialiujų žemès ir miško naudojimo salygu patvirtinimo" dalinio pakeitimo" // Agrarinès reformos biuletenis, $\mathrm{Nr} .33,1996$, p. 17--57.

Iteikta 19990826

\section{PROPERTY VALUATION BY MULTIPLE CRITERIA METHODS}

\section{Malienẻ, E. Zavadskas, A. Kaklauskas, S. Raslanas}

Su m mary

Multiple criteria valuation methods are widely used in real estate valuation all over the world. In USA, UK and other countries these methods are part of techniques based on comparative and reinstatement values as well as on income of use. They are used in valuating various property characteristics, ie its location or obsolescence degree. In Germany, however, multiple criteria valuation technique refers to a separate group of property valuation methods applied when market data are unavailable or insufficient (ie purchasing, selling or renting prices are not known). The above methods have been used for real estate valuation since 1976. Dr. H. E. Auerhammer [1] was the first to apply these approaches to solving real estate valuation problem caused by the scarcity of market data. These methods supplemented with systems of criteria developed by other authors were later applied to particular cases when three major commonly used property valuation methods could not be applied. Thus, $\mathrm{K}$. Gablenz [2] suggests using the method described in assessing plots intended for agriculture, while B. Bischoff [3] offers to use it for determining the investments into plots. R. Vogel [4] thinks that the approach may be used for determining the approximate value of land, whereas G. Sommer and P. Zimmermann [5] and Piehler [6] developed a system of criteria to be used as a part of the method described in determining the differences between the value of quantitative and qualitative characteristics of an object and its market value. T. Gierardy and R. Moeckel [7] described the advantages and disadvantages of methods based on multiple criteria analysis. The above methods are widely used in Germany for property valuation, the peak of their application being associated with the unification of East and West Germany in 1990 [8].

Multiple criteria analysis presented in this paper for property valuation may be used to the advantage of various interested parties (see Fig 1). The representatives of various parties including appraisers, buyers, sellers and investors may use it for their particular purposes:

- appraiser may apply this method to real estate value analysis for determining the market, use and other values of real estate being mortgaged, ensured, privatised, divided or nationalised;

- investor may rely on it for more efficient use of this property;

- buyer may use it for choosing property which would satisfy his personal needs to the best advantage;

- seller has to determine the market price of his property that would ensure its competitive ability on the market.

To satisfy all the needs described multiple criteria valuation method presented in the paper may be successfully used. To show its efficiency the solution of a sample problem, representing a real case is provided.

Vida MALIENÉ. Doctoral student. Dept of Building Technology and Management. Vilnius Gediminas Technical University, Saulètekio al. 11, 2040 Vilnius, Lithuania.

A graduate of Vilnius Gediminas Technical University. MSc (1996). Research visits to Bonn Friedrich-Wilhelm University (Germany, 1997/1998), Leipzig Higher School of Technology, Economics and Culture (Germany, 1998). Research interests: real estate valuation and management, land survey.

Edmundas Kazimieras ZAVADSKAS. Doctor Habil, Professor. Rector of Vilnius Gediminas Technical University. Member of Lithuanian Academy of Sciences. Member of Ukrainian Academy of Technological Cybernetics. Vilnius Gediminas Technical University, Saulètekio al. 11, 2040 Vilnius, Lithuania.

In 1973 Dr degree in building structures. Professor at the Dept of Building Technology and Management. In 1987 Dr Habil degree (problems of building technology and management). Research visits to Moscow Civil Engineering Institute, Leipzig and Aachen Technical University. He maintains close academic links with the universities of Aalborg (Denmark), Salford and Glamorgan (Great Britain), Poznan University of Technology (Poland), Leipzig Higher School of Technology, Economics and Culture (Germany) and Aachen Technical University (Germany). Member of international organizations. Member of steering and programme committees of many international conferences. Member of editorial boards of some research journals. Author of monographs in Lithuanian, English, German and Russian. Research interests: building technology and management, decision-making theory, automation in design, expert systems.

Artūras KAKLAUSKAS. Doctor Habil, Associate Professor. Dept of Building Technology and Management. Vilnius Gediminas Technical University, Sauletekio al. 11, 2040 Vilnius, Lithuania.

A graduate of Vilnius Civil Engineering Institute (since 1990 Vilnius Technical University) (1984, civil engineer). PhD (1990). Research visits to Aalborg University (Denmark, 1991), University of Glamorgan (UK, 1993/1995). Author and co-author of 4 monographs and more than 50 papers. Research interests: multiple criteria decision-making, expert systems, total quality management, computer-aided design.

Saulius RASLANAS. Doctor, Associate Professor. Dept of Building Technology and Management. Vilnius Gediminas Technical University, Sauletekio al. 11, 2040 Vilnius, Lithuania.

A graduate of Vilnius Civil Engineering Institute (since 1990 Vilnius Technical University) (1984, civil engineer). $\mathrm{PhD}$ (1992). Research visits to Horsens Higher School of Technology (Denmark, 1995), Leipzig Higher School of Technology, Economics and Culture (Germany, 1996). Author of 13 papers. Research interests: real estate valuation and management. 